\title{
BAX Translocation Is a Critical Event in Neuronal Apoptosis: Regulation by Neuroprotectants, BCL-2, and Caspases
}

\author{
Girish V. Putcha, Mohanish Deshmukh, and Eugene M. Johnson Jr \\ Departments of Neurology and Molecular Biology and Pharmacology, Washington University School of Medicine, \\ St. Louis, Missouri 63110
}

\begin{abstract}
Members of the BCL-2 family of proteins either promote or repress programmed cell death. Here we report that neonatal sympathetic neurons undergoing apoptosis after nerve growth factor (NGF) deprivation exhibited a protein synthesisdependent, caspase-independent subcellular redistribution of BAX from cytosol to mitochondria, followed by a loss of mitochondrial cytochrome $c$ and cell death. Treatment with elevated concentrations of the neuroprotectants $\mathrm{KCl}$ or cAMP at the time of deprivation prevented BAX translocation and cytochrome $c$ release. However, administration of $\mathrm{KCl}$ or cAMP $12 \mathrm{hr}$ after NGF withdrawal acutely prevented loss of mitochondrial cytochrome $c$, but not redistribution of BAX; rescue with NGF acutely prevented both events. Overexpression of $\mathrm{Bcl}-2$ neither altered the normal subcellular localization of BAX nor prevented
\end{abstract}

its redistribution with deprivation but did inhibit the subsequent release of cytochrome $c$, caspase activation, and cell death. $\mathrm{Bcl}-2$ overexpression did not prevent cell death induced by cytoplasmic microinjection of cytochrome $c$ into NGF-deprived competent-to-die neurons. These observations suggest that the subcellular redistribution of BAX is a critical event in neuronal apoptosis induced by trophic factor deprivation. BCL-2 acts primarily, if not exclusively, at the level of mitochondria to prevent BAX-mediated cytochrome $c$ release, whereas NGF, $\mathrm{KCl}$, or cAMP may abort the apoptotic program at multiple checkpoints.

Key words: apoptosis; cAMP; cell death; depolarization; neuron; neuroprotective agents
Recent evidence implicates the mitochondrion as a critical site at which different apoptotic signals converge. Findings in some non-neuronal models of cell death suggest that a death signal induces translocation of a BH3-containing, proapoptotic BCL-2 family member to the mitochondria, followed by the release of mitochondrial proteins, such as cytochrome $c$, via an unknown mechanism that may involve the permeability transition pore (PTP) and/or a channel formed by proapoptotic BCL-2 family proteins (Li et al., 1998; Luo et al., 1998; Gross et al., 1999). Once released, cytochrome $c$ forms a complex with Apaf-1 and procaspase-9, which in the presence of ATP or dATP, becomes activated, resulting in further caspase activation, cleavage of cellular substrates, and cell death. However, several questions remain. What is the normal subcellular localization of endogenous BAX in neuronal cells that require Bax expression for cell death? Does BAX translocation require an apoptotic stimulus? Is $\mathrm{BAX}$ redistribution necessary for cytochrome $c$ release? Where do BCL-2, caspases, and various neuroprotectants act in this process?

\footnotetext{
Received April 19, 1999; revised June 16, 1999; accepted June 18, 1999.

This work was supported by National Institutes of Health Grant AG-12947 (E.M.J.) and a Paralyzed Veterans of America Spinal Cord Research Foundation grant (M.D.). We thank Drs. C. Michael Knudson (University of Iowa, Iowa City, IA) and Stanley Korsmeyer (Dana Farber Cancer Institute, Boston, MA) for the Bax-deficient mice; Drs. Jean-Claude Martinou (Serono Pharmaceutical Research Institute, Geneva, Switzerland) and Susumu Tonegawa (Massachusetts Institute of Technology, Boston, MA) for the $\mathrm{Bcl}-2$ transgenic mice; and Dr. Anu Srinivasan (Idun Pharmaceuticals, La Jolla, CA) for the CM1 antibody. We also thank Krista Moulder, Dr. Brian Tsui-Pierchala, Charles Harris, Melanie Leitner, and Patricia A. Osborne for critical review of this manuscript; Dr. Malú Tansey for assistance with immunoblots; and Mary Bloomgren for secretarial assistance.

Correspondence should be addressed to Dr. Eugene M. Johnson, Jr., Department of Molecular Biology and Pharmacology, Washington University School of Medicine, 4566 Scott Avenue, Box 8103, St. Louis, MO 63110.

Copyright (C) 1999 Society for Neuroscience $0270-6474 / 99 / 197476-10 \$ 05.00 / 0$
}

We examined these questions by using the model of trophic factor deprivation in sympathetic neurons. Neonatal sympathetic neurons require nerve growth factor (NGF) for their survival (Levi-Montalcini and Booker, 1960; Gorin and Johnson, 1979; Crowley et al., 1994). In the absence of NGF these neurons undergo an apoptotic cell death (Edwards et al., 1991; Deckwerth and Johnson, 1993), which requires de novo protein synthesis (Martin et al., 1988) and the development of competence-to-die (Deshmukh and Johnson, 1998). This death is inhibited by caspase inhibitors (Troy et al., 1996; McCarthy et al., 1997), such as boc-aspartyl(OMe)-fluoromethylketone (BAF) (Deshmukh et al., 1996), and neuroprotective agents, such as $\mathrm{KCl}$ and cAMP (Rydel and Greene, 1988; Koike et al., 1989; Edwards et al., 1991; Deckwerth and Johnson, 1993; Franklin et al., 1995). Most important, in contrast to other model systems in which BAX translocation has been studied, sympathetic neurons absolutely require the endogenous expression of Bax to undergo apoptosis induced by trophic factor deprivation (Deckwerth et al., 1996). However, because neither the mRNA nor protein level of BAX increases during NGF deprivation-induced apoptosis, BAX must be regulated post-translationally (Greenlund et al., 1995).

Here we report that NGF-deprived sympathetic neurons induced macromolecular synthesis-dependent, caspase-independent subcellular redistribution of BAX, followed by the loss of mitochondrial cytochrome $c$, caspase activation, and apoptosis. Neuroprotective agents, such as $\mathrm{KCl}$ and cAMP, blocked the redistribution of both BAX and cytochrome $c$ when added at the time of deprivation but prevented only cytochrome $c$ release when administered $12 \mathrm{hr}$ after NGF withdrawal. Overexpression of $\mathrm{Bcl}-2$ neither altered the normal subcellular localization of BAX nor prevented its redistribution with deprivation but did inhibit the subsequent release of cytochrome $c$, caspase activation, and cell 
death. These findings indicate that the subcellular redistribution of BAX is a critical event in neuronal apoptosis induced by trophic factor deprivation. Although BCL-2 acted primarily, if not exclusively, at the level of mitochondria to prevent BAX-mediated cytochrome $c$ release, neuroprotective agents such as $\mathrm{KCl}$ or cAMP aborted the apoptotic program at multiple checkpoints.

\section{MATERIALS AND METHODS}

Reagents. All reagents were purchased from Sigma (St. Louis, MO) unless otherwise stated. Collagenase and trypsin were purchased from Worthington Biochemical (Freehold, NJ). The caspase inhibitor, bocaspartyl $(O \mathrm{Me}$ )-fluoromethylketone (BAF), was purchased from Enzyme Systems Products (Livermore, CA). The membrane-permeable cAMP analog, 8-(4-chlorophenylthio)-adenosine $3^{\prime}: 5^{\prime}$-cyclic monophosphate (CPT-cAMP), was used as the source of cAMP. CM1 polyclonal antibody, a gift from Dr. Anu Srinivasan (Idun Pharmaceuticals, La Jolla, CA), was raised against the 13-amino-acid peptide CRGTELDCGIETD, which is found at the $\mathrm{C}$ terminus of the p20 subunit of caspase- 3 (Armstrong et al., 1997; Namura et al., 1998; Srinivasan et al., 1998b). Medium lacking NGF (AM0) consisted of Eagle's MEM with Earl's salts (Life Technologies, Gaithersburg, MD) supplemented with $10 \%$ fetal bovine serum, $2 \mathrm{~mm}$ L-glutamine, $100 \mathrm{U} / \mathrm{ml}$ penicillin, $100 \mu \mathrm{g} / \mathrm{ml}$ streptomycin, $20 \mu \mathrm{M}$ fluorodeoxyuridine, $20 \mu \mathrm{M}$ uridine, and $3.3 \mu \mathrm{g} / \mathrm{ml}$ aphidicolin. AM50 medium consisted of AM0 medium plus $50 \mathrm{ng} / \mathrm{ml}$ mouse 2.5S NGF (Harlan Bioproducts, Indianapolis, IN). The breeding and genotyping of Bcl-2-overexpressing and Bax-deficient mice have been described previously (Martinou et al., 1994; Knudson et al., 1995; Deckwerth et al., 1996).

Sympathetic neuronal cultures. Primary cultures of sympathetic neurons were established from the superior cervical ganglia of neonatal mice by using a modification of a previously described method (Johnson et al., 1983; Deckwerth et al., 1996; Easton et al., 1997). Briefly, the dissected ganglia were treated with collagenase $(1 \mathrm{mg} / \mathrm{ml})$ and then trypsin $(2.5$ $\mathrm{mg} / \mathrm{ml}$ ) for $30 \mathrm{~min}$ each at $37^{\circ} \mathrm{C}$. The ganglia were triturated, and the dissociated cells were plated on collagen-coated dishes in AM50.

We observed that neurons from inbred C57BL/6 mice exhibited a loss of mitochondrial cytochrome $c$ and commitment-to-die $\sim 4-6 \mathrm{hr}$ earlier than neurons from Sprague Dawley rats or outbred ICR mice (see Figs. 1e, 5a; Deckwerth and Johnson, 1993; Deshmukh and Johnson, 1998). We believe that these shifts may be attributable to species and strain differences. Unless indicated otherwise, all control experiments were conducted with $\mathrm{C} 57 \mathrm{BL} / 6$ mice, the background strain for both the $B a x$-deficient and $B c l-2$ transgenic mice.

Culture conditions. Sympathetic neuronal cultures were grown in AM50 for 4-5 d and then either maintained in AM50 or treated as follows. For NGF deprivation the cultures were rinsed with AM0, followed by the addition of AM0 containing goat anti-mouse 2.5S NGF neutralizing antiserum (anti-NGF) (Ruit et al., 1990). For NGF deprivation in the presence of various reagents, $1 \mu \mathrm{g} / \mathrm{ml}$ cycloheximide, $40 \mathrm{~mm}$ $\mathrm{KCl}, 400 \mu \mathrm{M}$ CPT-cAMP, or $50 \mu \mathrm{M}$ BAF was added to AM0 containing anti-NGF. For acute rescue experiments in which NGF, KCl, or CPTcAMP was readded to cultures after $12 \mathrm{hr}$ of NGF deprivation, the cultures were rinsed with AM0 and then incubated in AM0 medium containing $300 \mathrm{ng} / \mathrm{ml} \mathrm{NGF}, 40 \mathrm{~mm} \mathrm{KCl}$, or $400 \mu \mathrm{M}$ CPT-cAMP, each in the presence of $50 \mu \mathrm{M}$ BAF.

Immunocytochemistry. Neuronal cultures were immunostained as described previously (Easton et al., 1997; Deshmukh and Johnson, 1998). Briefly, sympathetic neurons (1500-3000 cells) were grown on collagencoated two-well glass chamber slides (Nalge Nunc, Naperville, IL) in the appropriate medium. Cultures were washed with PBS and fixed with freshly prepared $4 \%$ paraformaldehyde in PBS (PFA) for $30 \mathrm{~min}$ at $4^{\circ} \mathrm{C}$. Cultures then were washed with PBS and Tris-buffered saline (TBS; 100 $\mathrm{mm}$ Tris- $\mathrm{HCl}$ and $0.9 \% \mathrm{NaCl}, \mathrm{pH} 7.6$ ), exposed to blocking solution [TBS containing 5\% donkey serum (Chemicon, Temecula, CA) and $0.3 \%$ Triton X-100] for $30 \mathrm{~min}$ at room temperature (RT) and incubated in the appropriate primary antibody diluted in TBS, $1 \%$ donkey serum, and $0.3 \%$ Triton $\mathrm{X}-100$ at $4^{\circ} \mathrm{C}$ overnight. Cultures then were washed with TBS and incubated for $2-4 \mathrm{hr}$ at $4^{\circ} \mathrm{C}$ in the dark with the appropriate secondary antibody diluted in TBS, $1 \%$ donkey serum, and $0.3 \%$ Triton $\mathrm{X}-100$. Cultures were washed with TBS and stained with $1 \mu \mathrm{g} / \mathrm{ml}$ bisbenzimide (Hoechst 33258; Molecular Probes, Eugene, OR) for 15-20 $\mathrm{min}$ at RT. After being rinsed with TBS, the cultures were coverslipped and examined by fluorescence microscopy. Phospho-c-Jun, Fos, and activated caspases 3 and 7 were detected with the following rabbit polyclonal antibodies at the indicated dilutions: anti-phospho-c-Jun (Ser63) (1:200; New England Biolabs, Beverly, MA), anti-Fos (1:3000; Santa Cruz Biotechnology, Santa Cruz, CA) and CM1 (1:5000; Idun Pharmaceuticals, La Jolla, CA). The secondary antibody was a Cy3conjugated donkey anti-rabbit IgG $(1.5 \mathrm{mg} / \mathrm{ml}$; Jackson ImmunoResearch, West Grove, PA) diluted 1:400. Cytochrome $c$ (1:1000; PharMingen, San Diego, CA), cytochrome oxidase VIc (1:500; Molecular Probes), and human and mouse BCL-2 (1:250; PharMingen) were detected with mouse monoclonal primary antibodies and FITC-conjugated donkey anti-mouse secondary antibody $(0.6 \mathrm{mg} / \mathrm{ml}$; Jackson ImmunoResearch) diluted 1:300.

BAX was detected with a rat monoclonal primary antibody (1:250; PharMingen) and a Cy3-conjugated anti-rat secondary antibody (1.5 $\mathrm{mg} / \mathrm{ml}$; Jackson ImmunoResearch) diluted 1:400. Several antibodies to BAX, both commercial and proprietary, were tested for specificity in our system. All of the BAX antibodies that we tested stained tissues from Bax-deficient mice. However, the faint, diffuse staining pattern seen in $B a x^{-/-}$sympathetic neurons with the PharMingen antibody used in these studies did not change during NGF deprivation.

Cell counts: commitment point experiments. Sympathetic neurons from $B c l-2$ transgenic mice and their wild-type littermates were deprived of NGF as described above. At various times after deprivation the cultures were rinsed with AM0 and then incubated in AM50 for 5-7 d. Neurons then were counted after being washed with PBS, fixed with freshly prepared $4 \%$ PFA for $30 \mathrm{~min}$ at $4^{\circ} \mathrm{C}$, washed again with $\mathrm{PBS}$, and stained with toluidine blue as described previously (Deckwerth and Johnson, 1993; Deshmukh et al., 1996).

Cell counts: BAX and cytochrome c immunocytochemistry. Sympathetic neurons that had been maintained in NGF for 4-5 d in AM50 were deprived of NGF in the presence of the caspase inhibitor BAF (as described above). At various times after deprivation or acute rescue by readdition of $\mathrm{NGF}, \mathrm{KCl}$, or $\mathrm{CPT}$-cAMP the cultures were fixed and immunostained with anti-BAX and/or anti-cytochrome $c$ antibodies. NGF-maintained sympathetic neurons exhibited diffuse BAX and punctate cytochrome $c$ staining patterns. With NGF deprivation the cells showed punctate BAX and diffuse cytochrome $c$ staining patterns. For each time point the number of cells that had acquired a punctate staining pattern for BAX or had lost the punctate staining pattern for cytochrome $c$ was determined by a naïve observer from a random sampling of $100-250$ cells. For the double immunocytochemistry experiments the staining patterns for both BAX and cytochrome $c$ were assessed in the same neuron. All experiments were conducted in the presence of BAF to prevent any cell loss that otherwise would affect the counts.

Microinjections and quantitation of cell death. These experiments were performed as described previously (Deshmukh and Johnson, 1998). Briefly, sympathetic neurons were maintained in NGF for $4 \mathrm{~d}$ and treated for $24-48 \mathrm{hr}$ with NGF, anti-NGF, or anti-NGF plus $1 \mu \mathrm{g} / \mathrm{ml}$ cycloheximide. Cells then were microinjected with $5 \mathrm{mg} / \mathrm{ml}$ bovine cytochrome $c$ and rhodamine dextran dye. At each time point after the injections the number of microinjected cells that remained viable was determined and expressed as a percentage of the total number of microinjected cells.

Statistics. When indicated, statistical significance was determined by a Student's $t$ test or by a Mann-Whitney Rank Sum test for parametric and nonparametric data, respectively.

\section{RESULTS}

\section{BAX undergoes caspase-independent subcellular redistribution after NGF deprivation in sympathetic neurons}

Previous studies in several models of programmed cell death (PCD) show that BAX translocates from the cytosol to mitochondria when overexpressed and/or in response to certain death signals (Hsu et al., 1997; Wolter et al., 1997; Eskes et al., 1998; Gross et al., 1998; Rosse et al., 1998; Saikumar et al., 1998; Zhang et al., 1998; Finucane et al., 1999; McGinnis et al., 1999). We examined whether the translocation of endogenous BAX occurred in NGF-deprived sympathetic neurons. These studies were done in the presence of the caspase inhibitor BAF to prevent any cell death that otherwise might have complicated the determination of cell numbers. BAX redistribution also was observed in the absence of BAF; however, because redistribution was followed very rapidly by cell death in the absence of caspase 


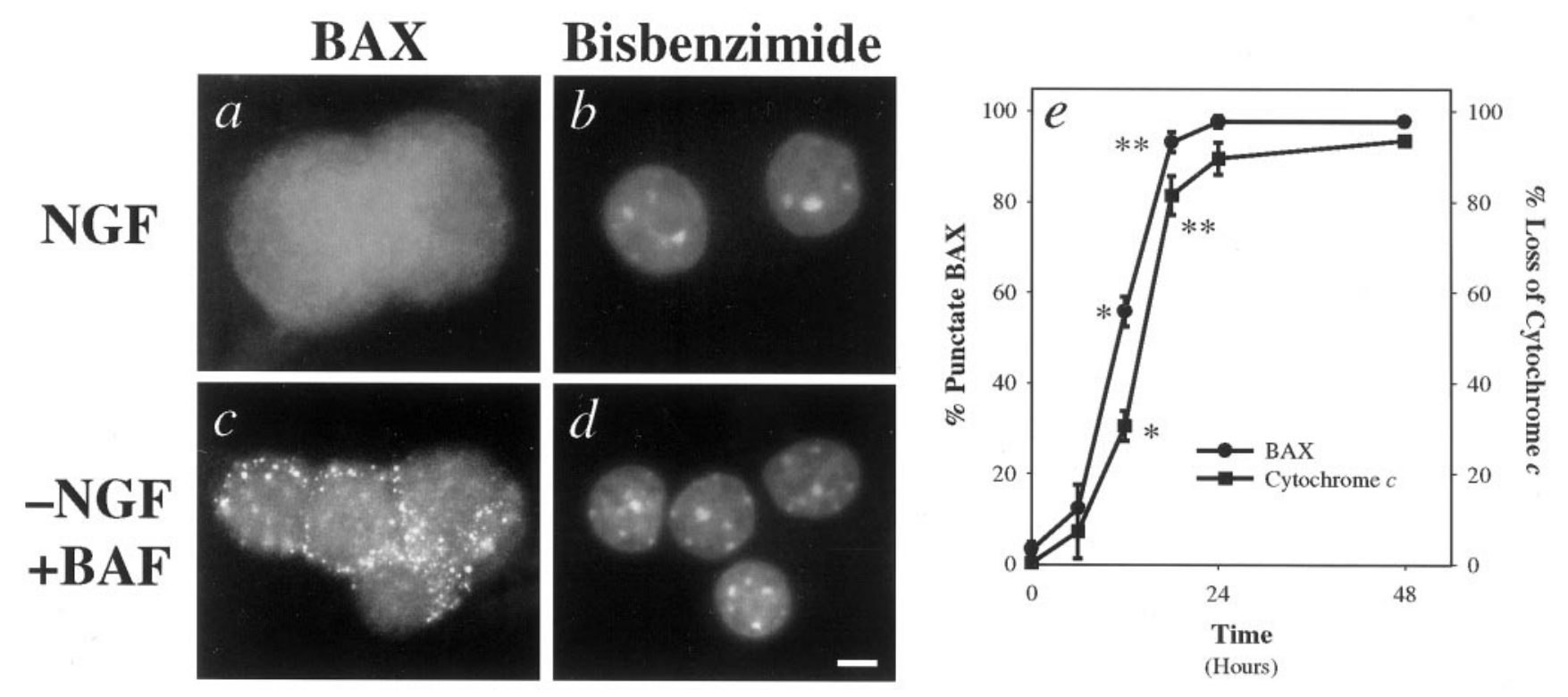

Figure 1. NGF deprivation in sympathetic neurons induces subcellular redistribution of BAX, followed by a loss of mitochondrial cytochrome $c$. Shown are representative photomicrographs of neurons immunostained for $\operatorname{BAX}(a, c)$ and the corresponding bisbenzimide-stained nuclei $(b, d)$. Neurons were maintained for $5 \mathrm{~d}$ in vitro (DIV) in the presence of NGF and then switched to medium containing NGF $(a, b)$ or deprived of NGF in the presence of $50 \mu \mathrm{M} \mathrm{BAF}$ for an additional $48 \mathrm{hr}(c, d)$. The time course of development of punctate BAX staining $(\bullet)$ and loss of punctate cytochrome $c$ staining $(\square)$ are shown $(e)$. At various times after NGF deprivation, sympathetic neurons were fixed and immunostained for BAX or cytochrome $c$. Then the number of cells exhibiting punctate BAX or diff use cytochrome $c$ staining was determined, with 200 -250 cells counted for each time point. Mean \pm SEM; $n \geq 3$ independent experiments. Points indicated by asterisks are statistically different $\left({ }^{*} p=0.002 ;{ }^{* *} p=0.035\right)$. Scale bar, $5 \mu \mathrm{m}$.

inhibition, counting cells in the absence of BAF yielded a misleading estimate of the number of cells in which BAX had redistributed (data not shown).

We examined the subcellular localization of BAX by using immunocytochemistry rather than subcellular fractionation because of the impracticality of the latter, given the limited number of primary neurons obtained from each sympathetic ganglion in mice. Recently, two reports (using models of PCD that have not been shown to require endogenous BAX for apoptosis) suggest that BAX in non-neuronal cell lines does not translocate from the cytosol to mitochondria but instead that BAX already at mitochondria undergoes a conformational change that exposes an N-terminal epitope (Goping et al., 1998; Desagher et al., 1999). The immunocytochemistry results reported here cannot distinguish clearly between these two possibilities because the antibody used recognizes an epitope in the $\mathrm{N}$ terminus of BAX. However, because the preponderance of evidence in non-neuronal cell lines (see above) suggests that BAX undergoes translocation to mitochondria and not merely a conformational change at mitochondria, we shall, therefore, refer to the apparent redistribution we observed as translocation.

NGF-maintained sympathetic neurons primarily exhibited a diff use staining pattern, consistent with a predominantly cytosolic localization for BAX (Fig. 1a). A small fraction of cells displayed a faint, punctate staining pattern, suggesting that, although BAX normally may reside primarily in the cytosol, a small amount may exist in association with organelle membranes in NGFmaintained cells (data not shown). The pattern of BAX staining was altered in NGF-deprived sympathetic neurons from a diff use, cytosolic pattern to a punctate pattern, consistent with the redistribution of BAX to intracellular membranes (Fig. 1b). Punctate BAX staining colocalized extensively with mitochondrial markers, such as cytochrome oxidase subunit VIc and Mitotracker Orange $\mathrm{CM}-\mathrm{H}_{2}$ TMRos (data not shown). As described previ- ously (Deshmukh and Johnson, 1998; Neame et al., 1998), NGF deprivation also induced a change in the pattern of cytochrome $c$ staining from a punctate, mitochondrial pattern to a diffuse, cytosolic pattern (Fig. $2 b, f, j$ ).

The time courses for BAX and cytochrome $c$ redistribution after NGF deprivation in sympathetic neurons were determined (see Fig. 1e). Fifty percent of the neurons exhibited a punctate, mitochondrial BAX staining pattern by $11-13 \mathrm{hr}$, with nearly all of the neurons displaying redistribution of BAX by $24 \mathrm{hr}$. BAX redistribution was followed rapidly, but not instantaneously, by a loss of mitochondrial cytochrome $c$ staining. Fifty percent of the neurons exhibited a diffuse, cytosolic pattern of cytochrome $c$ staining by $14-16 \mathrm{hr}$, with essentially all of the cells showing a loss of mitochondrial cytochrome $c$ by $24 \mathrm{hr}$. The time course with which sympathetic neurons became committed to die (i.e., could not be rescued by NGF readdition) paralleled the time course of cytochrome $c$ release, suggesting that the loss of mitochondrial cytochrome $c$ commits these cells to die (see Figs. 1e, 5; data not shown).

As seen in Figure 1e, $\mathrm{BAX}$ redistribution to the mitochondria preceded loss of mitochondrial cytochrome $c$ by $1-3 \mathrm{hr}$, suggesting that a transient "state" exists in a sympathetic neuron undergoing NGF deprivation-induced death in which both BAX and cytochrome $c$ show mitochondrial localization. Immunocytochemistry for BAX and cytochrome $c$ confirmed this prediction (Fig. 2). Sympathetic neurons maintained in NGF existed in "state 1," in which BAX was distributed primarily throughout the cytoplasm and cytochrome $c$ was localized mitochondrially (Fig. $2 a-d, m)$. After $24 \mathrm{hr}$ of NGF deprivation nearly all of the cells resided in "state 3 ," with BAX and cytochrome $c$ predominantly localized to the mitochondria and cytosol, respectively (Fig. 2i$m$ ). However, at an intermediate time point such as $12 \mathrm{hr}$ after deprivation, we found evidence that cells transited through a short-lived "state 2," in which both BAX and cytochrome $c$ were 

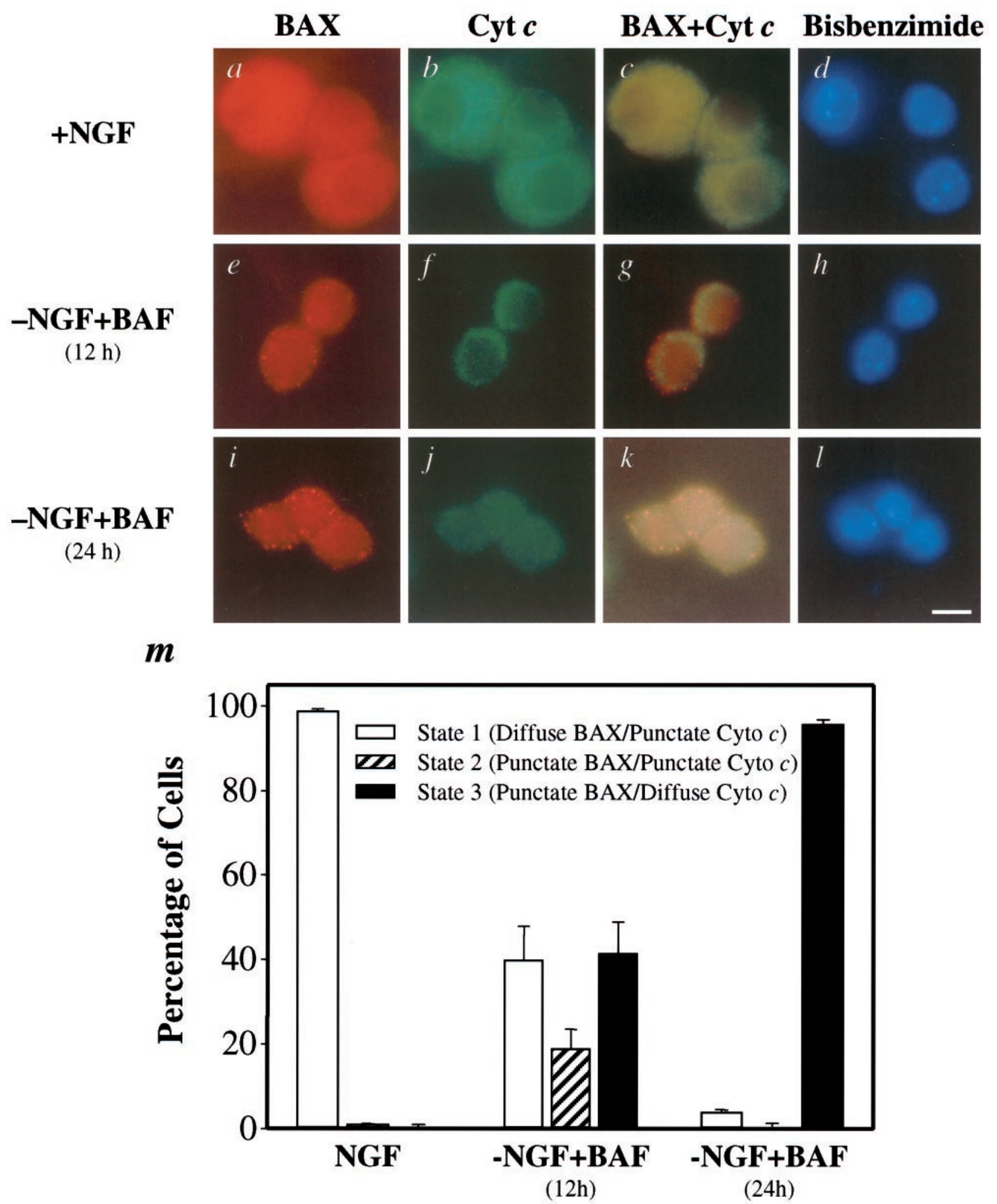

Figure 2. BAX and cytochrome $c$ undergo subcellular redistribution during NGF deprivation in sympathetic neurons. Shown are representative photomicrographs of neurons immunostained for $\operatorname{BAX}(a, e, i)$, cytochrome $c(b, f, j)$, or both $(c, g, k)$ and the corresponding bisbenzimide-stained nuclei $(d, h, l)$. Neurons either were maintained in NGF $(a-d)$ or were deprived of NGF in the presence of $50 \mu \mathrm{M}$ BAF for $12 \mathrm{hr}(e-h)$ or $24 \mathrm{hr}(i-l)$. The cells were fixed and immunostained for BAX and cytochrome $c$. Then the number of neurons $(m)$ exhibiting diff use BAX and punctate cytochrome $c$ staining (State 1), punctate BAX and punctate cytochrome $c$ staining (State 2), or punctate BAX and diff use cytochrome $c$ staining (State 3) was determined, with $100-150$ cells counted for each time point. Mean \pm SEM; $n \geq 3$. Scale bar, $10 \mu \mathrm{m}$. 


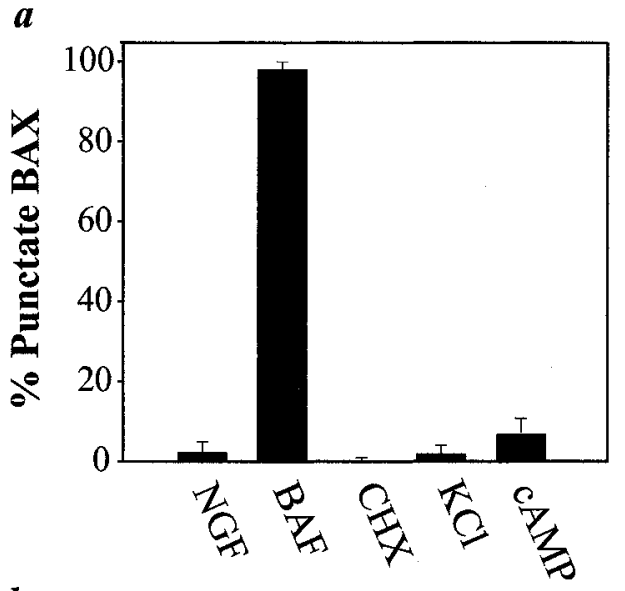

b

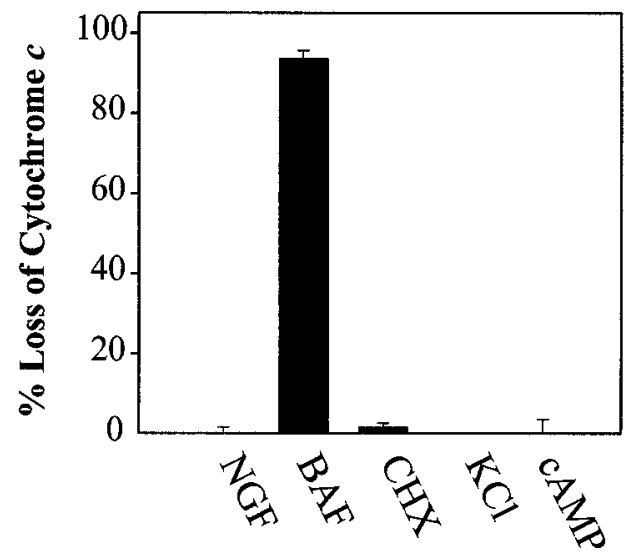

Figure 3. Effects of neuroprotectants on the redistribution of BAX and cytochrome $c$ after NGF deprivation in sympathetic neurons. Neurons (5 DIV) were maintained in NGF or deprived of NGF in the presence of 50 $\mu \mathrm{M}$ BAF, $1 \mu \mathrm{g} / \mathrm{ml}$ cycloheximide $(C H X), 40 \mathrm{~mm} \mathrm{KCl}$, or $400 \mu \mathrm{M} \mathrm{CPT}-$ cAMP. After $48 \mathrm{hr}$ the neurons were fixed and immunostained for BAX (a) or cytochrome $c(b)$. Then the number of cells exhibiting punctate BAX staining or diffuse cytochrome $c$ staining was determined, with $200-250$ cells counted for each condition. Mean \pm SEM; $n \geq 3$.

localized mitochondrially (Fig. $2 e-h, m$ ). Thus, NGF deprivation in sympathetic neurons induced a caspase-independent subcellular redistribution of $\mathrm{BAX}$, followed by a loss of cytochrome $c$ from the mitochondria.

\section{Redistribution of BAX and Cytochrome $c$ is inhibited by the neuroprotective agents cycloheximide, cAMP, and $\mathrm{KCl}$}

Inhibitors of macromolecular synthesis such as cycloheximide prevent NGF deprivation-induced cell death in sympathetic neurons (Martin et al., 1988), aborting the PCD pathway upstream of cytochrome $c$ release and caspase activation (Deshmukh and Johnson, 1998; Neame et al., 1998) (data not shown). To determine whether de novo protein synthesis was required for the redistribution of BAX during neuronal death, we examined the ability of cycloheximide to block this event. NGF-deprived, cycloheximide-saved neurons maintained a diffuse pattern of BAX staining even after 48 hr of NGF deprivation (Fig. $3 a$ ). Accordingly, cycloheximide also prevents the loss of mitochondrial cytochrome $c$ during NGF deprivation (Fig. 3b) (Deshmukh and Johnson, 1998; Neame et al., 1998).

Although NGF is the physiological survival factor for sympa- thetic neurons in vivo, several other agents promote their survival in vitro. Of these, two robust neuroprotectants are the cellpermeable cAMP analog, CPT-cAMP, and depolarizing concentrations of $\mathrm{KCl}$ (Rydel and Greene, 1988; Koike et al., 1989; Edwards et al., 1991; Deckwerth and Johnson, 1993; Franklin et al., 1995). Therefore, we examined the effects of these agents on the redistribution of BAX and cytochrome $c$ during sympathetic neuronal death. Even after $48 \mathrm{hr}$ of NGF deprivation in the presence of either $\mathrm{KCl}(40 \mathrm{~mm})$ or CPT-cAMP $(400 \mu \mathrm{M})$, neurons exhibited minimal redistribution of $\mathrm{BAX}$ and cytochrome $c$ (Fig. 3a,b).

Thus, NGF deprivation in sympathetic neurons induced a macromolecular synthesis-dependent, caspase-independent redistribution of BAX and cytochrome $c$. Potent neuroprotectants, such as $\mathrm{KCl}$ and cAMP, prevented both events.

\section{Rescue with NGF, KCl, or cAMP prevents further release of cytochrome $c$, but only NGF acutely prevents further redistribution of BAX during neuronal death}

NGF readdition within the first $12 \mathrm{hr}$ after deprivation can fully rescue sympathetic neurons from neonatal rats (Edwards et al., 1991; Deckwerth and Johnson, 1993). Thereafter, sympathetic neurons start becoming irreversibly committed to die. Only $50 \%$ can be rescued by NGF readdition after $22 \mathrm{hr}$ of deprivation; essentially none can be rescued after $48 \mathrm{hr}$ of deprivation. (In neurons from $\mathrm{C} 57 \mathrm{BL} / 6$ mice, these time points are shifted $\sim 4-6$ hr earlier than in neurons from Sprague Dawley rats; see Materials and Methods.) Like NGF, either $\mathrm{KCl}$, cAMP, or BAF can arrest sympathetic neuronal death post-translationally. Indeed, the time courses with which sympathetic neurons are rescued by NGF, KCl, cAMP, or BAF are indistinguishable (Edwards et al., 1991; Deckwerth and Johnson, 1993; Franklin et al., 1995; Deshmukh et al., 1996).

As described above, treatment with elevated concentrations of $\mathrm{KCl}$ or $\mathrm{cAMP}$ at the time of $\mathrm{NGF}$ withdrawal prevented the redistribution of BAX and cytochrome $c$ (Fig. 3). To study the mechanisms by which NGF, KCl, or cAMP arrests sympathetic neuronal death post-translationally, we examined whether treatment with each of these agents $12 \mathrm{hr}$ after NGF withdrawal acutely prevented further redistribution of BAX and cytochrome c. Cells were deprived of NGF in the presence of BAF for $12 \mathrm{hr}$, and the pattern of BAX or cytochrome $c$ staining was assessed. In parallel cultures $\mathrm{NGF}, \mathrm{KCl}$, or cAMP was added back, and the pattern of BAX or cytochrome $c$ staining was determined $12 \mathrm{hr}$ later. As shown in Figure $4 b$, rescue with NGF, KCl, or cAMP acutely prevented any further loss of mitochondrial cytochrome $c$ in NGF-deprived sympathetic neurons, indicating that each of these agents rapidly can suppress cytochrome $c$ release. However, only $\mathrm{NGF}$, but not $\mathrm{KCl}$ or $\mathrm{cAMP}$, prevented the further redistribution of $\mathrm{BAX}$ to mitochondria. These results suggested that cAMP and $\mathrm{KCl}$ acted after BAX redistributed to mitochondria to prevent cytochrome $c$ release and cell death in sympathetic neurons.

If cells were rescued acutely with NGF and observed $5 \mathrm{~d}$ (not $12 \mathrm{hr}$ ) later, all cells returned to "state 1" (see Fig. 2) in which BAX was diffuse and cytochrome $c$ was punctate (data not shown). We currently are investigating whether this phenomenon reflects reversibility in $\mathrm{BAX}$ redistribution or degradation of mitochondrial BAX and de novo synthesis of cytosolic BAX. 


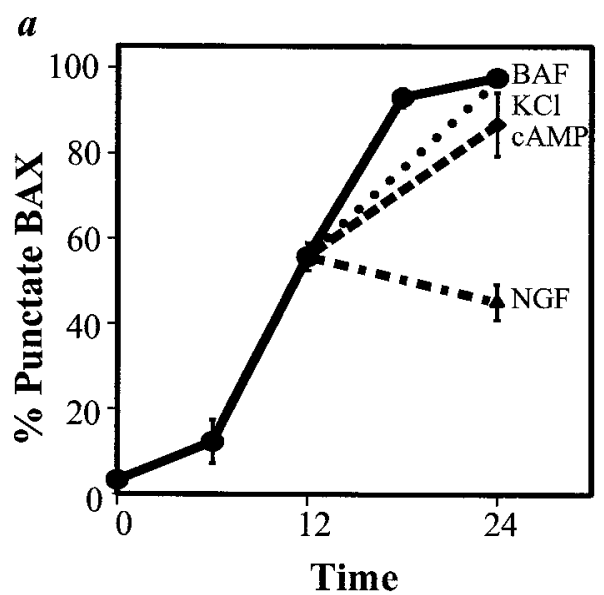

(Hours)

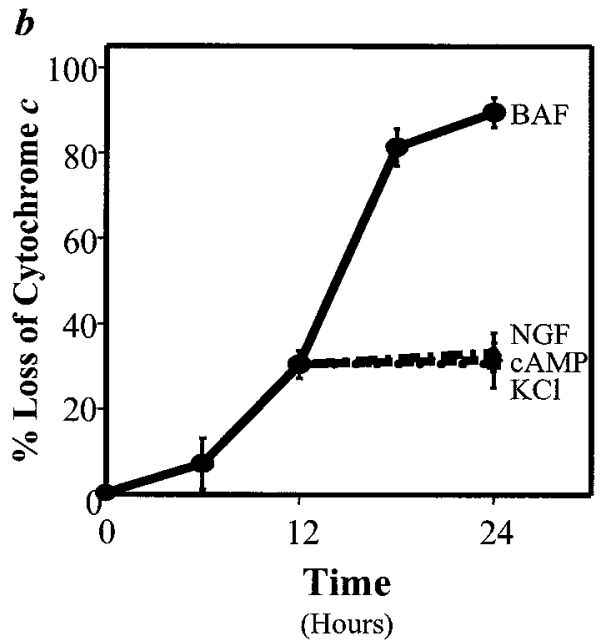

Figure 4. NGF, KCl, and cAMP differ in their ability to rescue the redistribution of BAX and cytochrome $c$ during sympathetic neuronal death. At $0,6,12,18$, or $24 \mathrm{hr}$ after NGF deprivation in the presence of $50 \mu \mathrm{M}$ BAF $(\bullet)$, sympathetic neurons were fixed and immunostained for BAX ( $a$ ) or cytochrome $c(b)$. In parallel cultures the neurons that were deprived of NGF in the presence of $50 \mu \mathrm{M}$ BAF for $12 \mathrm{hr}$ were washed and rescued with $300 \mathrm{ng} / \mathrm{ml} \mathrm{NGF}(\mathbf{\Delta}), 40 \mathrm{~mm} \mathrm{KCl}(\mathbf{\square})$, or $400 \mu \mathrm{M}$ CPT-cAMP $(\diamond)$. After an additional $12 \mathrm{hr}$ the number of cells exhibiting punctate BAX or diff use cytochrome $c$ staining was determined, with 200-250 cells counted for each time point. In $a$, the neurons rescued with NGF were statistically different from those rescued with $\mathrm{BAF}, \mathrm{KCl}$, or CPT-cAMP $(p<0.001)$. In $b$, the neurons rescued with BAF were statistically different from those rescued with NGF, KCl, or CPT-cAMP $(p<0.001)$. Mean \pm SEM; $n \geq 3$.

\section{Overexpression of $\mathrm{Bcl}-2$ inhibits cytochrome $\mathrm{c}$ release, caspase activation, and cell death, but not BAX redistribution, during sympathetic neuronal death}

Sympathetic neurons from Bax-deficient mice do not undergo apoptosis after NGF deprivation (Deckwerth et al., 1996). Similarly, overexpression of $B c l-2$ or inhibition of caspases-by either genetic deletion or peptide inhibitors-protects numerous neuronal subpopulations, including sympathetic neurons, from developmental and induced cell death (Martinou et al., 1994; Greenlund et al., 1995; Deshmukh et al., 1996; Kuida et al., 1996, 1998; McCarthy et al., 1997; Hakem et al., 1998; Woo et al., 1998). To compare mechanistically the sites of action for BCL-2, BAX, and caspases, we examined sympathetic neuronal death in transgenic mice overexpressing $B c l-2$. These mice, which have been described extensively (Martinou et al., 1994), overexpress human $B c l-2$ behind the neuron-specific enolase promoter, which is expressed from embryonic day 12.5 into adulthood. Western blot analysis confirmed expression of the transgene in sympathetic neurons (data not shown).

To assess the extent of protection afforded by overexpression of $B c l-2$, we determined the time course of commitment-to-die in neurons from $\mathrm{Bcl}-2$ transgenic mice. Sympathetic neurons from both transgenic and wild-type mice were deprived of NGF. At various times after deprivation, NGF was readded and cell survival was assessed 5-7 d later. As shown in Figure 5, Bcl-2 overexpression significantly delayed commitment-to-die from $\sim 12 \mathrm{hr}$ to $\sim 3 \mathrm{~d}$; however, unlike Bax deletion, overexpression of $B c l-2$ did not prevent NGF deprivation-induced cell death completely in sympathetic neurons. Other studies (e.g., c-Jun phosphorylation and c-fos induction) indicated that $\mathrm{Bcl}-2$ overexpression aborted NGF deprivation-induced cell death at a point that is mechanistically indistinguishable from Bax deletion (Deckwerth et al., 1998) (data not shown).

Bax deletion prevents the loss of cytochrome $c$ from mitochondria (Deshmukh and Johnson, 1998). Similarly, overexpression of $B c l-2$ or $B c l-X_{\mathrm{L}}$ inhibits cytochrome $c$ release induced by different apoptotic stimuli in several non-neuronal cell lines (Kharbanda et

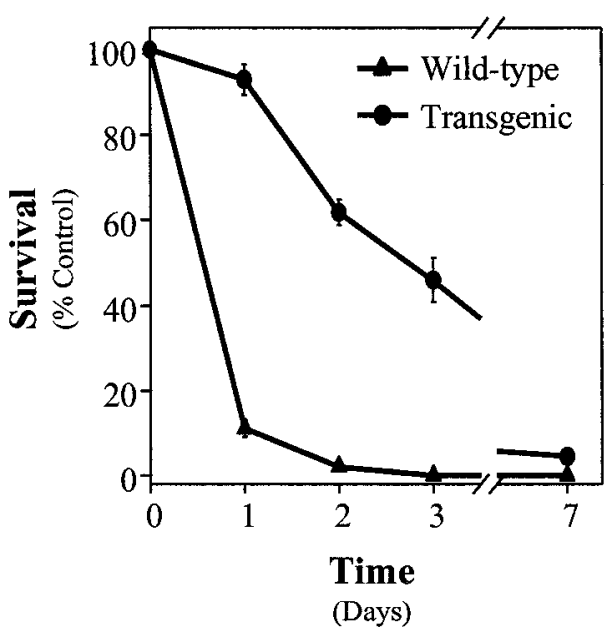

Figure 5. Overexpression of $B c l-2$ inhibits NGF deprivation-induced cell death in sympathetic neurons. Neurons from wild-type $(\mathbf{\Delta})$ and $\mathrm{Bcl}$-2 transgenic $(-$ mice were maintained in NGF for $5 \mathrm{~d}$ and then deprived of NGF for various periods. At 1, 2, 3, or $7 \mathrm{~d}$ after deprivation the cells were washed and rescued with $50 \mathrm{ng} / \mathrm{ml} \mathrm{NGF}$. Then $5 \mathrm{~d}$ later the neurons were fixed, stained with toluidine blue, and counted. Mean \pm SEM; $n \geq 3$.

al., 1997; Kluck et al., 1997; Yang et al., 1997; Duckett et al., 1998; Srinivasan et al., 1998a; Finucane et al., 1999). As shown in Figure $6 b, B c l-2$ overexpression inhibited the loss of mitochondrial cytochrome $c$ during NGF deprivation in sympathetic neurons. Accordingly, we found that overexpression of $\mathrm{Bcl}-2$ inhibited caspase activation, as determined by staining with the polyclonal antibody CM1, which recognizes activated caspases 3 and 7 (data not shown).

To determine whether overexpression of $B c l-2$ affects the subcellular localization of endogenous BAX during cell death, we examined the time course of BAX redistribution in sympathetic neurons from $\mathrm{Bcl}-2$ transgenic mice. As shown in Figure $6 a, B c l-2$ 
$a$

Figure 6. Overexpression of $\mathrm{Bcl}-2$ inhibits the redistribution of cytochrome $c$, but not BAX, in NGF-deprived sympathetic neurons. Neurons from wild-type $(\boldsymbol{\Delta})$ or $\mathrm{Bcl}-2$ transgenic $(\bullet)$ mice were maintained in NGF for $5 \mathrm{~d}$ and then deprived of NGF in the presence of $50 \mu \mathrm{M}$ BAF for various periods. At $0,12,24$, or $48 \mathrm{hr}$ after deprivation the cells were fixed and immunostained for BAX $(a)$ or cytochrome $c(b)$; then the number of cells exhibiting punctate BAX or diffuse cytochrome $c$ staining was determined, with 200-250 cells counted for each time point. Mean \pm SEM; $n \geq 3$.

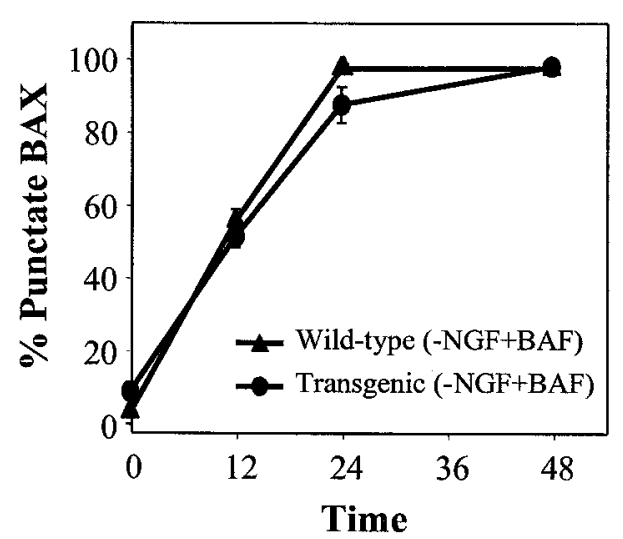

(Hours) $\boldsymbol{b}$

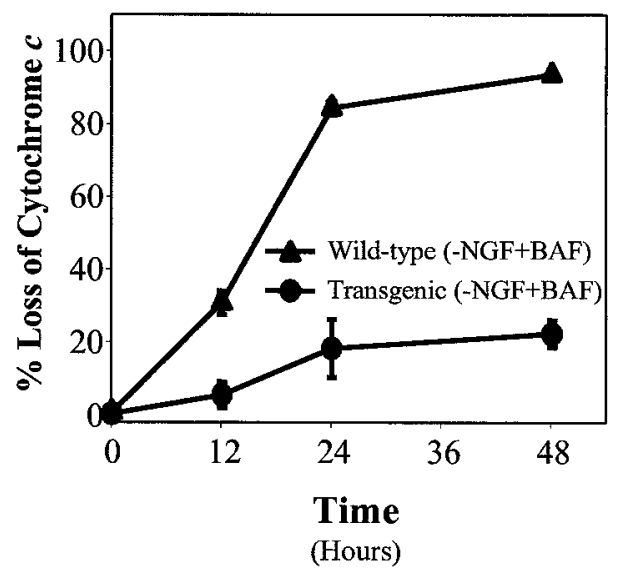

overexpression neither prevented nor altered the rate of subcellular redistribution of endogenous BAX after NGF deprivation. We also found that overexpression of $\mathrm{Bcl}-2$ had no obvious effect on the distribution of endogenous BAX in NGF-maintained sympathetic neurons (Fig. $6 a, 0 \mathrm{hr}$; data not shown). Thus, the results shown in Figure 6 indicate that the overexpression of $\mathrm{Bcl}-2$ in sympathetic neurons inhibited cell death induced by NGF deprivation by preventing BAX-mediated cytochrome $c$ release.

\section{Overexpression of $\mathrm{Bcl}-2$ does not inhibit cell death induced by microinjection of cytochrome $\boldsymbol{c}$}

As described above, the overexpression of $\mathrm{Bcl}-2$ did not prevent $\mathrm{BAX}$ redistribution, but it did inhibit the loss of mitochondrial cytochrome $c$ and caspase activation (Fig. 6). These findings indicate that BCL-2 acted at the level of mitochondria to inhibit NGF deprivation-induced cell death in sympathetic neurons. Recent reports suggest that overexpression of anti-apoptotic BCL-2 family members, such as $B c l-2$ and $B c l-X_{\mathrm{L}}$, can prevent caspase activation and cell death downstream of or independent from cytochrome $c$ release (Li et al., 1997; Rosse et al., 1998). To determine whether BCL-2 can prevent neuronal death even after cytochrome $c$ translocates to the cytosol, we examined whether overexpression of $\mathrm{Bcl}-2$ inhibited the cell death induced by microinjection of cytochrome $c$ into NGF-deprived sympathetic neurons. Previously, we have shown that microinjection of cytochrome $c$ into NGF-maintained neurons does not induce cell death. However, microinjection of cytochrome $c$ into NGFdeprived, cycloheximide-treated or NGF-deprived, Bax-deficient neurons induces rapid cell death that is inhibitable by BAF, suggesting that NGF withdrawal induces two parallel processes, both of which are required for cell death: loss of mitochondrial cytochrome $c$ and the development of competence-to-die (Deshmukh and Johnson, 1998).

As shown in Figure 7, microinjection of cytochrome $c$ into NGF-deprived, $B c l$-2-overexpressing sympathetic neurons in the presence or absence of cycloheximide induced cell death. Furthermore, the extent and time course of death after the injection of cytochrome $c$ was not affected by overexpression of $\mathrm{Bcl}-2$. These findings also indicate that $B c l-2$ overexpression-like $B a x$ deletion and cycloheximide treatment-did not prevent the development of competence-to-die. Taken together, the results shown in Figures 6 and 7 indicate that BCL-2 appears to act solely at the level of mitochondria to prevent BAX-mediated cytochrome $c$ release and cell death in NGF-deprived sympathetic neurons.

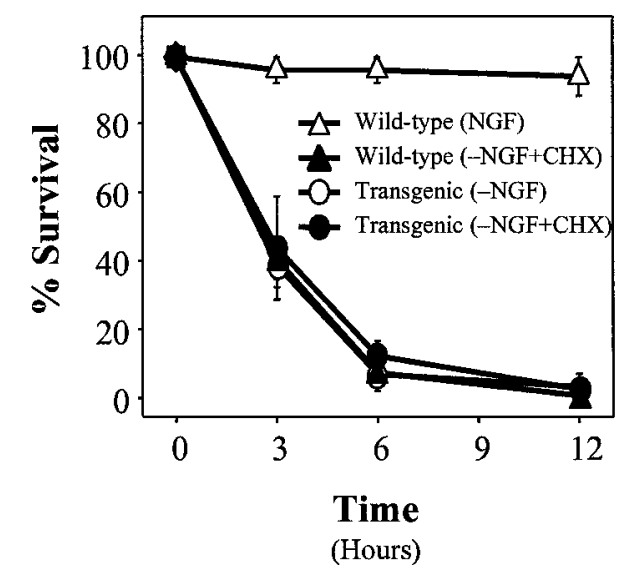

Figure 7. Overexpression of $B c l-2$ does not prevent cell death induced by cytoplasmic microinjection of cytochrome $c$ into NGF-deprived sympathetic neurons. Cells from wild-type ( $\triangle$ or $\mathbf{\Delta}$ ) or $B c l-2$ transgenic $(O$ or $\bullet)$ mice were maintained in NGF for $5 \mathrm{~d}$ and treated for 24-48 hr with NGF $(\triangle)$, anti-NGF $(\bigcirc)$, or anti-NGF plus $1 \mu \mathrm{g} / \mathrm{ml}$ cycloheximide $(\mathrm{CHX} ; \mathbf{\Delta}$ and ๑). Then the cells were microinjected with $5 \mathrm{mg} / \mathrm{ml}$ bovine cytochrome $c$ and rhodamine dextran dye. At each time point after the injections the number of microinjected cells that remained viable was determined and expressed as a percentage of the total number of microinjected cells. Mean \pm SEM; $n \geq 3$.

\section{DISCUSSION}

\section{BAX and cytochrome $c$ undergo subcellular redistribution during sympathetic neuronal death}

Despite the widespread expression of Bax in vivo, Bax-deficient mice exhibit relatively modest defects in non-neuronal lineages, perhaps because of functional redundancy with other proapoptotic BCL-2 family members (Knudson et al., 1995). In contrast, their phenotype in neuronal lineages, whether central or peripheral, is dramatic (Deckwerth et al., 1996; Miller et al., 1997; Shindler et al., 1997; White et al., 1998). For example, despite the coexpression of multiple proapoptotic BCL-2 family members, cell death induced by trophic factor deprivation in sympathetic and motor neurons is remarkably dependent on BAX alone. However, because neither the mRNA nor protein level of BAX increases during NGF deprivation-induced apoptosis in sympathetic neurons (Greenlund et al., 1995), BAX must be regulated post-translationally.

Recent evidence suggests that this regulation occurs at the level of subcellular localization of BAX. In several models of cell death 


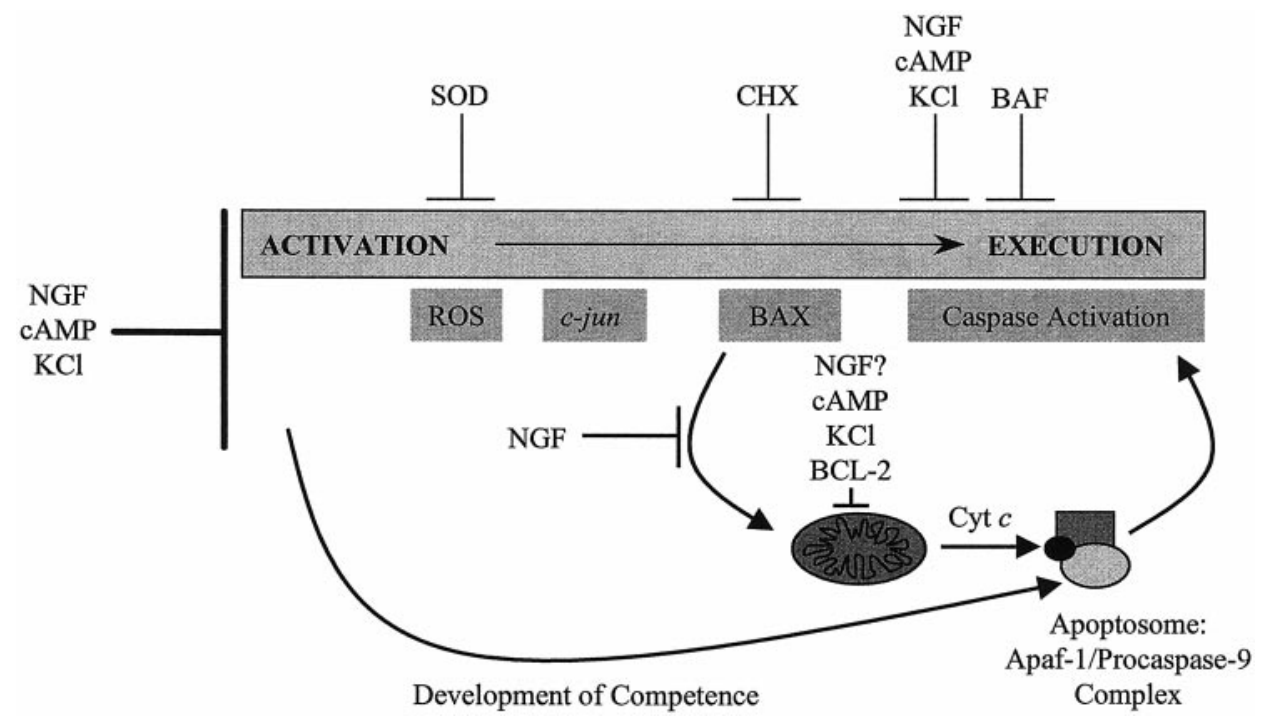

Figure 8. Schematic diagram of the sequence of critical events that occurs during sympathetic neuronal death induced by NGF deprivation. ROS, Reactive oxygen species; $S O D$, superoxide dismutase; $C H X$, cycloheximide; cyt $c$, cytochrome $c$. CHX appears to inhibit the induction of a gene required for the translocation of BAX to mitochondria. The identity of the specific gene product, the expression of which may be regulated by c-Jun, is unknown. Although $\mathrm{NGF}, \mathrm{KCl}$, or cAMP can block the cell death pathway in sympathetic neurons at multiple checkpoints, only NGF, the physiological survival factor, inhibits apoptosis at all known points before cytochrome $c$ release and caspase activation. the overexpression of $B a x$ and/or certain death signals induce translocation of BAX from the cytosol to mitochondria (Hsu et al., 1997; Wolter et al., 1997), followed by cytochrome $c$ release, mitochondrial dysfunction, caspase activation, and cell death (Gross et al., 1998; Rosse et al., 1998; Saikumar et al., 1998; Zhang et al., 1998; Finucane et al., 1999; McGinnis et al., 1999). However, to our knowledge, none of these non-neuronal models of PCD requires endogenous Bax expression for cell death; in fact, a few have been shown specifically not to require BAX (Knudson et al., 1995). Moreover, Bax overexpression per se drives mitochondrial translocation (Rosse et al., 1998; our unpublished observations) and induces a cell death that may not require caspases and is not purely apoptotic (Xiang et al., 1996).

Neonatal sympathetic neurons deprived of NGF undergo an apoptotic cell death that requires de novo protein synthesis (Martin et al., 1988), Bax expression (Deckwerth et al., 1996), and the development of competence-to-die (Deshmukh and Johnson, 1998). In this study we found that NGF deprivation in sympathetic neurons induced a protein synthesis-dependent, caspaseindependent redistribution of BAX from cytosol to mitochondria (see Figs. 1-3). This was followed rapidly, but not instantaneously, by cytochrome $c$ release and commitment-to-die (see Figs. 2, 5). The identity of the specific gene product(s) induced during NGF deprivation and required for BAX redistribution remains unknown.

Recently, Goping et al. (1998) and Desagher et al. (1999) suggested that BAX does not translocate from the cytosol to mitochondria but instead that BAX already at mitochondria undergoes a conformational change that exposes an N-terminal epitope. The immunocytochemical findings reported here cannot distinguish clearly between the translocation of BAX to mitochondria and a conformational change in BAX at mitochondria. We currently are examining the feasibility of subcellular fractionation experiments to resolve this issue.

The precise mechanism by which BAX mediates loss of mitochondrial cytochrome $c$ is unclear. Recent evidence suggests that two potentially interrelated mechanisms may mediate this release: the calcium-inducible, cyclosporin A (CsA)-sensitive permeability transition pore (PTP) and a $\mathrm{Mg}^{2+}$-sensitive, CsAinsensitive pathway that depends on BAX (or perhaps more generally on BH3 domain-containing, proapoptotic BCL-2 family members) (Eskes et al., 1998; Marzo et al., 1998; Narita et al.,
1998). If BAX and the PTP mediate two biochemically and molecularly distinct pathways for cytochrome $c$ release, four observations argue against a significant role for the PTP in sympathetic neuronal death. First, primary sympathetic neurons absolutely require BAX alone for cytochrome $c$ release (Deshmukh and Johnson, 1998), caspase activation, and apoptosis (Deckwerth et al., 1996). Second, mitochondria in NGF-deprived neurons do not exhibit the ultrastructural changes such as swelling and outer membrane rupture that should accompany permeability transition (Martin et al., 1988; Martinou et al., 1999). Third, nontoxic concentrations of CsA neither prevented nor delayed cytochrome $c$ release or cell death induced by NGF deprivation in murine sympathetic neurons (our unpublished observations). Fourth, we find that a significant delay in time occurred between cytochrome $c$ release and the loss of mitochondrial membrane potential (our unpublished observations). Thus, our data suggest that permeability transition does not mediate cytochrome $c$ release during trophic factor deprivation-induced cell death in neurons.

\section{Acute rescue with NGF, but not $\mathrm{KCl}$ or CAMP, prevents redistribution of $\mathrm{BAX}$}

Cell death induced by NGF deprivation in sympathetic neurons can be arrested late in the apoptotic process by the readdition of NGF (Deckwerth and Johnson, 1993), KCl (Franklin et al., 1995), cAMP (Edwards et al., 1991), or BAF (Deshmukh et al., 1996). In fact, the time courses with which sympathetic neurons are rescued by $\mathrm{NGF}, \mathrm{KCl}, \mathrm{cAMP}$, or BAF are indistinguishable. However, BAF, but not NGF, can inhibit sympathetic neuronal death after cytochrome $c$ release and caspase activation (Deshmukh and Johnson, 1998).

In this study we have identified other important differences in the post-translational mechanisms by which $\mathrm{NGF}, \mathrm{KCl}$, cAMP, or BAF aborts NGF deprivation-induced cell death in sympathetic neurons. Specifically, we found that $\mathrm{NGF}, \mathrm{KCl}$, or cAMP, but not $\mathrm{BAF}$, prevented redistribution of BAX and cytochrome $c$ when added at the time of deprivation (see Fig. 3). Similarly, acute rescue with $\mathrm{NGF}, \mathrm{KCl}$, or cAMP, but not $\mathrm{BAF}$, after $12 \mathrm{hr}$ of deprivation prevented further loss of cytochrome $c$ from mitochondria (see Fig. 4b). However, only NGF acutely prevented further redistribution of BAX (see Fig. 4a). These observations suggest that $\mathrm{KCl}$ or $\mathrm{CAMP}$ can act after $\mathrm{BAX}$ has redistributed to 
mitochondria to prevent cytochrome $c$ release and cell death in sympathetic neurons. Our results cannot exclude the possibility that NGF also may act after BAX translocation to inhibit cytochrome $c$ release. These findings also imply that, although NGF, $\mathrm{KCl}$, or cAMP each can abort the cell death cascade in sympathetic neurons at multiple checkpoints, only NGF, the physiological survival factor, may inhibit apoptosis at all known points before cytochrome $c$ release and caspase activation.

\section{$\mathrm{Bcl}-2$ overexpression prevents redistribution of cytochrome $c$, but not BAX, during PCD}

Bax deletion and, to a lesser extent, caspase inhibition protect sympathetic neurons against NGF deprivation-induced apoptosis (Deckwerth et al., 1996; Deshmukh et al., 1996; Troy et al., 1996; McCarthy et al., 1997). In this study we found that Bcl-2 overexpression significantly delayed, but did not prevent, sympathetic neuronal death (see Fig. 5). Overexpression of $\mathrm{Bcl}-2$ aborted the apoptotic cascade induced by NGF deprivation at a point that is mechanistically indistinguishable from Bax deletion.

In several non-neuronal cell lines the overexpression of $B c l-2$ or $B c l-X_{\mathrm{L}}$ prevents-and Bax promotes-the translocation of cytochrome $c$ and cell death (Kharbanda et al., 1997; Kluck et al., 1997; Yang et al., 1997; Gross et al., 1998; Rosse et al., 1998; Finucane et al., 1999). To examine further the actions of BAX and BCL-2 in regulating the loss of cytochrome $c$ from mitochondria in primary neurons, we examined the subcellular localization of BAX and cytochrome $c$ during NGF deprivation in Bcl-2overexpressing sympathetic neurons. We observed that $\mathrm{Bcl}-2$ overexpression, like Bax deletion, prevented the loss of mitochondrial cytochrome $c$ to approximately the same extent that it inhibited cell death induced by NGF deprivation (compare Figs. $5,6 b)$. We also found that overexpression of $\mathrm{Bcl}-2$ did not prevent-nor did it alter the kinetics of-the subcellular redistribution of endogenous BAX (see Fig. $6 a$ ).

Last, whether BCL-2 or BCL-X $\mathrm{L}_{\mathrm{L}}$ can prevent caspase activation and cell death downstream of or independent from cytochrome $c$ release is unclear ( $\mathrm{Li}$ et al., 1997; Rosse et al., 1998; Zhivotovsky et al., 1998). Presumably, this anti-apoptotic activity would be related to the interaction of BCL-2 or BCL-X $\mathrm{L}_{\mathrm{L}}$ with Apaf-1 at the level of the apoptosome (Pan et al., 1998). However, in NGF-deprived sympathetic neurons in the presence or absence of cycloheximide, we observed that $\mathrm{Bcl}-2$ overexpression neither prevented nor altered the rate of cell death induced by microinjection of cytochrome $c$ (see Fig. $6 c$ ). Taken together, these observations indicate that BCL-2 functions primarily, if not exclusively, at the level of mitochondria to inhibit BAX-mediated cytochrome $c$ release.

\section{The role of macromolecular synthesis in apoptosis}

Unlike apoptosis induced by NGF deprivation in sympathetic neurons, which requires de novo protein synthesis, Fas- or TNFmediated cell death is facilitated by the inhibition of macromolecular synthesis. Recently, several groups reported that activation of the Fas and TNF-R1 receptors causes receptor oligomerization, recruitment and activation of procaspase- 8 , and $\mathrm{N}$-terminal cleavage of BID; this is followed by translocation of the C-terminal fragment to mitochondria, cytochrome $c$ release, and cell death (Li et al., 1998; Luo et al., 1998; Gross et al., 1999). In light of our findings, we propose that a critical difference between macromolecular synthesis-dependent (e.g., NGF deprivation in sympathetic neurons) and independent (e.g., Fas or TNF treatment in non-neuronal cells) paradigms of cell death may be that the former require the expression of new gene products to induce the translocation of a BH3-domaincontaining, proapoptotic BCL-2 family member to mitochondria, whereas the latter do not. In NGF-deprived sympathetic neurons, BAX alone appears to serve the role of this proapoptotic, BH3containing protein that mediates the loss of cytochrome $c$, caspase activation, and cell death (Fig. 8). In other models of cell death the identity of the proapoptotic, $\mathrm{BH} 3$-containing protein responsible for the loss of mitochondrial cytochrome $c$ may vary according to cell type and apoptotic stimulus.

\section{REFERENCES}

Armstrong RC, Aja TJ, Hoang KD, Gaur S, Bai X, Alnemri ES, Litwack G, Karanewsky DS, Fritz LC, Tomaselli KJ (1997) Activation of the Ced3/ICE-related protease Cpp32 in cerebellar granule neurons undergoing apoptosis, but not necrosis. J Neurosci 17:553-562.

Crowley C, Spencer SD, Nishimura MC, Chen KS, Pitts-Meek S, Armanini MP, Ling LH, MacMahon SB, Shelton DL, Levinson AD (1994) Mice lacking nerve growth factor display perinatal loss of sensory and sympathetic neurons yet develop basal forebrain cholinergic neurons. Cell 76:1001-1011.

Deckwerth TL, Johnson Jr EM (1993) Temporal analysis of events associated with programmed cell death (apoptosis) of sympathetic neurons deprived of nerve growth factor. J Cell Biol 123:1207-1222.

Deckwerth TL, Elliott JL, Knudson CM, Johnson Jr EM, Snider WD, Korsmeyer SJ (1996) Bax is required for neuronal death after trophic factor deprivation and during development. Neuron 17:401-411.

Deckwerth TL, Easton RM, Knudson CM, Korsmeyer SJ, Johnson Jr EM (1998) Placement of the $B c l-2$ family member Bax in the death pathway of sympathetic neurons activated by trophic factor deprivation. Exp Neurol 152:150-162.

Desagher S, Osen-Sand A, Nichols A, Eskes R, Montessuit S, Lauper S, Maundrell K, Antonsson B, Martinou J-C (1999) BID-induced conformational change in Bax is responsible for mitochondrial cytochrome $c$ release during apoptosis. J Cell Biol 144:891-901.

Deshmukh M, Johnson Jr EM (1998) Evidence of a novel event during neuronal death: development of competence-to-die in response to cytoplasmic cytochrome $c$. Neuron 21:695-705.

Deshmukh M, Vasilakos J, Deckwerth TL, Lampe PA, Shivers BD, Johnson Jr EM (1996) Genetic and metabolic status of NGF-deprived sympathetic neurons saved by an inhibitor of ICE family proteases. J Cell Biol 135:1341-1354.

Duckett CS, Li F, Wang Y, Tomaselli KJ, Thompson CB, Armstrong RC (1998) Human Iap-like protein regulates programmed cell death downstream of Bcl- $\mathrm{X}_{\mathrm{L}}$ and cytochrome $c$. Mol Cell Biol 18:608-615.

Easton RM, Deckwerth TL, Parsadanian AS, Johnson Jr EM (1997) Analysis of the mechanism of loss of trophic factor dependence associated with neuronal maturation: a phenotype indistinguishable from Bax deletion. J Neurosci 17:9656-9666.

Edwards SN, Buckmaster AE, Tolkovsky AM (1991) The death programme in cultured sympathetic neurones can be suppressed at the post-translational level by nerve growth factor, cyclic AMP, and depolarization. J Neurochem 57:2140-2143.

Eskes R, Antonsson B, Osensand A, Montessuit S, Richter C, Sadoul R, Mazzei G, Nichols A, Martinou J-C (1998) Bax-induced cytochrome $c$ release from mitochondria is independent of the permeability transition pore but highly dependent on $\mathrm{Mg}^{2+}$ ions. J Cell Biol 143:217-224.

Finucane DM, Bossy-Wetzel E, Waterhouse N, Cotter TG, Green DR (1999) Bax-induced caspase activation and apoptosis via cytochrome $c$ release from mitochondria is inhibitable by $\mathrm{Bcl}-\mathrm{X}_{\mathrm{L}}$. J Biol Chem 274:2225-2233.

Franklin JL, Sanz-Rodriguez C, Juhasz A, Deckwerth TL, Johnson Jr EM (1995) Chronic depolarization prevents programmed death of sympathetic neurons in vitro but does not support growth: requirement for $\mathrm{Ca}^{2+}$ influx but not Trk activation. J Neurosci 15:643-664.

Goping IS, Gross A, Lavoie JN, Nguyen M, Jemmerson R, Roth K, Korsmeyer SJ, Shore GC (1998) Regulated targeting of Bax to mitochondria. J Cell Biol 143:207-215.

Gorin PD, Johnson Jr EM (1979) Experimental autoimmune model of nerve growth factor deprivation: effects on developing peripheral sympathetic and sensory neurons. Proc Natl Acad Sci USA 76:5382-5386. Greenlund LJS, Korsmeyer SJ, Johnson Jr EM (1995) Role of Bcl-2 in 
the survival and function of developing and mature sympathetic neurons. Neuron 15:649-661.

Gross A, Jockel J, Wei MC, Korsmeyer SJ (1998) Enforced dimerization of Bax results in its translocation, mitochondrial dysfunction, and apoptosis. EMBO J 17:3878-3885.

Gross A, Yin XM, Wang K, Wei MC, Jockel J, Millman C, ErdjumentBromage H, Tempst P, Korsmeyer SJ (1999) Caspase-cleaved BID targets mitochondria and is required for cytochrome $c$ release, while $\mathrm{Bcl}-\mathrm{X}_{\mathrm{L}}$ prevents this release but not tumor necrosis factor-R1/Fas death. J Biol Chem 274:1156-1163.

Hakem R, Hakem A, Duncan GS, Henderson JT, Woo M, Soengas MS, Elia A, de la Pompa JL, Kagi D, Khoo W, Potter J, Yoshida R, Kaufman SA, Lowe SW, Penninger JM, Mak TW (1998) Differential requirement for caspase-9 in apoptotic pathways in vivo. Cell 94:339-352.

Hsu YT, Wolter KG, Youle RJ (1997) Cytosol-to-membrane redistribution of Bax and Bcl- $\mathrm{X}_{\mathrm{L}}$ during apoptosis. Proc Natl Acad Sci USA 94:3668-3672.

Johnson MI, Argiro V (1983) Techniques in the tissue culture of rat sympathetic neurons. Methods Enzymol 103:334-347.

Kharbanda S, Pandey P, Schofield L, Israels S, Roncinske R, Yoshida K, Bharti A, Yuan ZM, Saxena S, Weichselbaum R, Nalin C, Kufe D (1997) Role for Bcl- $\mathrm{X}_{\mathrm{L}}$ as an inhibitor of cytosolic cytochrome $c$ accumulation in DNA damage-induced apoptosis. Proc Natl Acad Sci USA 94:6939-6942.

Kluck RM, Bossy-Wetzel E, Green DR, Newmeyer DD (1997) The release of cytochrome $c$ from mitochondria: a primary site for Bcl-2 regulation of apoptosis. Science 275:1132-1136.

Knudson CM, Tung KS, Tourtellotte WG, Brown GA, Korsmeyer SJ (1995) Bax-deficient mice with lymphoid hyperplasia and male germ cell death. Science 270:96-99.

Koike T, Martin DP, Johnson Jr EM (1989) Role of $\mathrm{Ca}^{2+}$ channels in the ability of membrane depolarization to prevent neuronal death induced by trophic-factor deprivation: evidence that levels of internal $\mathrm{Ca}^{2+}$ determine nerve growth factor dependence of sympathetic ganglion cells. Proc Natl Acad Sci USA 86:6421-6425.

Kuida K, Zheng TS, Na S, Kuan C, Yang D, Karasuyama H, Rakic P, Flavell RA (1996) Decreased apoptosis in the brain and premature lethality in Cpp32-deficient mice. Nature 384:368-372.

Kuida K, Haydar TF, Kuan CY, Gu Y, Taya C, Karasuyama H, Su MS, Rakic P, Flavell RA (1998) Reduced apoptosis and cytochrome $c$-mediated caspase activation in mice lacking caspase-9. Cell 94:325-337.

Levi-Montalcini R, Booker B (1960) Destruction of the sympathetic ganglia in mammals by an antiserum to the nerve growth-promoting factor. Proc Natl Acad Sci USA 46:384-391.

Li F, Srinivasan A, Wang Y, Armstrong RC, Tomaselli KJ, Fritz LC (1997) Cell-specific induction of apoptosis by microinjection of cytochrome $c$ : $\mathrm{Bcl}-\mathrm{X}_{\mathrm{L}}$ has activity independent of cytochrome $c$ release. J Biol Chem 272:30299-30305.

Li HL, Zhu H, Xu CJ, Yuan JY (1998) Cleavage of BID by caspase-8 mediates the mitochondrial damage in the Fas pathway of apoptosis. Cell 94:491-501.

Luo X, Budihardjo I, Zou H, Slaughter C, Wang XD (1998) BID, a Bcl-2 interacting protein, mediates cytochrome $c$ release from mitochondria in response to activation of cell surface death receptors. Cell 94:481-490.

Martin DP, Schmidt RE, DiStefano PS, Lowry OH, Carter JG, Johnson Jr EM (1988) Inhibitors of protein synthesis and RNA synthesis prevent neuronal death caused by nerve growth factor deprivation. J Cell Biol 106:829-844.

Martinou I, Desagher S, Eskes R, Antonsson B, Andre E, Fakan S, Martinou J-C (1999) The release of cytochrome $c$ from mitochondria during apoptosis of NGF-deprived sympathetic neurons is a reversible event. J Cell Biol 144:883-889.

Martinou J-C, Dubois-Dauphin M, Staple JK, Rodriguez I, Frankowski H, Missotten M, Albertini P, Talabot D, Catsicas S, Pietra C (1994) Overexpression of $\mathrm{Bcl}-2$ in transgenic mice protects neurons from naturally occurring cell death and experimental ischemia. Neuron 13:1017-1030.

Marzo I, Brenner C, Zamzami N, Jurgensmeier JM, Susin SA, Vieira HLA, Prevost MC, Xie ZH, Matsuyama S, Reed JC, Kroemer G (1998) Bax and adenine nucleotide translocator cooperate in the mitochondrial control of apoptosis. Science 281:2027-2031.
McCarthy MJ, Rubin LL, Philpott KL (1997) Involvement of caspases in sympathetic neuron apoptosis. J Cell Sci 110:2165-2173.

McGinnis KM, Gnegy ME, Wang KKW (1999) Endogenous Bax translocation in SH-SY5Y human neuroblastoma cells and cerebellar granule neurons undergoing apoptosis. J Neurochem 72:1899-1906.

Miller TM, Moulder KL, Knudson CM, Creedon DJ, Deshmukh M, Korsmeyer SJ, Johnson Jr EM (1997) Bax deletion further orders the cell death pathway in cerebellar granule cells and suggests a caspaseindependent pathway to cell death. J Cell Biol 139:205-217.

Namura S, Zhu JM, Fink K, Endres M, Srinivasan A, Tomaselli KJ, Yuan JY, Moskowitz MA (1998) Activation and cleavage of caspase-3 in apoptosis induced by experimental cerebral ischemia. $\mathrm{J}$ Neurosci 18:3659-3668.

Narita M, Shimizu S, Ito T, Chittenden T, Lutz RJ, Matsuda H, Tsujimoto Y (1998) Bax interacts with the permeability transition pore to induce permeability transition and cytochrome $c$ release in isolated mitochondria. Proc Natl Acad Sci USA 95:14681-14686.

Neame SJ, Rubin LL, Philpott KL (1998) Blocking cytochrome $c$ activity within intact neurons inhibits apoptosis. J Cell Biol 142:1583-1593.

Pan GH, O'Rourke K, Dixit VM (1998) Caspase-9, Bcl-X ${ }_{\mathrm{L}}$, and Apaf-1 form a ternary complex. J Biol Chem 273:5841-5845.

Rosse T, Olivier R, Monney L, Rager M, Conus S, Fellay I, Jansen B, Borner C (1998) Bcl-2 prolongs cell survival after Bax-induced release of cytochrome $c$. Nature 391:496-499.

Ruit KG, Osborne PA, Schmidt RE, Johnson Jr EM, Snider WD (1990) Nerve growth factor regulates sympathetic ganglion cell morphology and survival in the adult mouse. J Neurosci 10:2412-2419.

Rydel RE, Greene LA (1988) cAMP analogs promote survival and neurite outgrowth in cultures of rat sympathetic and sensory neurons independently of nerve growth factor. Proc Natl Acad Sci USA 85:1257-1261.

Saikumar P, Dong Z, Patel Y, Hall K, Hopfer U, Weinberg JM, Venkatachalam MA (1998) Role of hypoxia-induced Bax translocation and cytochrome $c$ release in reoxygenation injury. Oncogene 17:3401-3415.

Shindler KS, Latham CB, Roth KA (1997) Bax deficiency prevents the increased cell death of immature neurons in $\mathrm{Bcl}-\mathrm{X}_{\mathrm{L}}$-deficient mice. J Neurosci 17:3112-3119.

Srinivasan A, Li F, Wong A, Kodandapani L, Smidt R, Krebs JF, Fritz LC, Wu JC, Tomaselli KJ (1998a) Bcl- $\mathrm{X}_{\mathrm{L}}$ functions downstream of caspase-8 to inhibit Fas- and tumor necrosis factor receptor 1-induced apoptosis of Mcf7 breast carcinoma cells. J Biol Chem 273:4523-4529.

Srinivasan A, Roth KA, Sayers RO, Shindler KS, Wong AN, Fritz LC, Tomaselli KJ (1998b) In situ immunodetection of activated caspase-3 in apoptotic neurons in the developing nervous system. Cell Death Differ 5:1004-1016.

Troy CM, Stefanis L, Prochiantz A, Greene LA, Shelanski ML (1996) The contrasting roles of ICE family proteases and interleukin-1- $\beta$ in apoptosis induced by trophic factor withdrawal and by copper/zinc superoxide dismutase down-regulation. Proc Natl Acad Sci USA 93:5635-5640.

White FA, Keller-Peck CR, Knudson CM, Korsmeyer SJ, Snider WD (1998) Widespread elimination of naturally occurring neuronal death in Bax-deficient mice. J Neurosci 18:1428-1439.

Wolter KG, Hsu YT, Smith CL, Nechushtan A, Xi XG, Youle RJ (1997) Movement of Bax from the cytosol to mitochondria during apoptosis. J Cell Biol 139:1281-1292.

Woo M, Hakem R, Soengas MS, Duncan GS, Shahinian A, Kagi D, Hakem A, McCurrach M, Khoo W, Kaufman SA, Senaldi G, Howard T, Lowe SW, Mak TW (1998) Essential contribution of caspase-3/ CPP32 to apoptosis and its associated nuclear changes. Genes Dev 12:806-819.

Xiang JL, Chao DT, Korsmeyer SJ (1996) Bax-induced cell death may not require interleukin $1-\beta$-converting enzyme-like proteases. Proc Natl Acad Sci USA 93:14559-14563.

Yang J, Liu XS, Bhalla K, Kim CN, Ibrado AM, Cai JY, Peng TI, Jones DP, Wang XD (1997) Prevention of apoptosis by Bcl-2: release of cytochrome $c$ from mitochondria blocked. Science 275:1129-1132.

Zhang H, Heim J, Meyhack B (1998) Redistribution of Bax from cytosol to membranes is induced by apoptotic stimuli and is an early step in the apoptotic pathway. Biochem Biophys Res Commun 251:454-459.

Zhivotovsky B, Orrenius S, Brustugun OT, Doskeland SO (1998) Injected cytochrome $c$ induces apoptosis. Nature 391:449-450. 